dents and not leave it up to individual faculty members.

In some universities bibliographic instruction librarians and their services are seen as non-essential or as the fat in the library's budget, while at other universities bibliographic instruction programs are expanding. In any case, decisions on the retention, expansion, or elimination of bibliographic instruction programs are often made without the benefit of data. It behooves the bibliographic instruction librarian to become familiar with survey techniques and to take responsibility for examining bib- liographic instruction contributions to library services. Most colleges and universities have experts on campus who can help librarians conduct surveys and interpret their results. In this case, the coordinator of instructional development from the Media Resources Center helped with the survey design, while a statistician from the Statistical Lab helped draw the sample and interpret the survey results. Conventional wisdom may believe that bibliographic instruction is a library service luxury but when belief is tested against data, conventional wisdom may be dispelled.

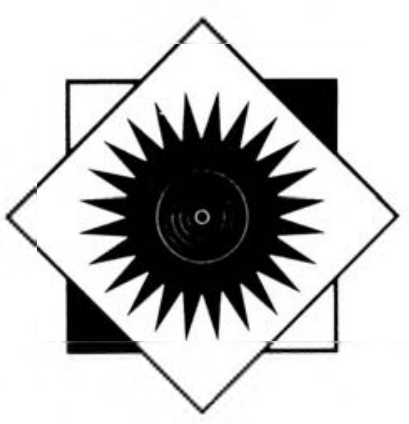

\title{
INNOVATIONS
}

\section{Humor and creativity: Preservation}

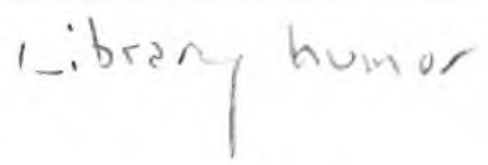

\author{
By Norman D. Stevens \\ Director \\ The Molesworth Institute
}

Even the most casual perusal of contemporary ephemeral library publications confirms the fact that the emergent field of preservation has become a fertile field for our imagination. The surprising wealth of library humor that now focuses on this aspect of librarianship deserves attention and analysis. Why should this arcane subject exercise the creative minds of librarians and result in the production of a wide range of what are meant to beeven if they aren't always-humorous items and events? Part of this may be simply the allure of a relatively new field but there may also be some darker underlying explanation.

Much of this humor is generated by preservation advocates themselves largely in the context of their continuing efforts to educate both staff and users. The theory, which I heartily endorse, seems to be that a light-hearted approach in respect to serious efforts to improve the behavior of staff and users in respect to their treatment of our precious books will get the message across in a more palatable fashion and might, thus, even result in actual positive changes in behavior. Whether or not this theory can be proven, it certainly is widely held.

Perhaps the best example is a splendid 3:55minute video, Handle With Care $(\$ 39.00)$, produced by Lora Hays at the New York University Libraries. In this offbeat video, which effectively utilizes imaginative fake paper sets, a careless young male patron demonstrates all the wrong ways to treat books to a background of strange comments by an off-screen narrator and weird sounds. As the video ends the reformed user finds true love as he helps an attractive, young, uninformed female patron learn how to treat library books properly.

This same kind of creative approach is often widely used in exhibits, such as that at the Fairfield University Library in 1988, which attempt to visually demonstrate to users the horrors of food and drink in the library and how, in other ways, poor treatment can damage library materials. Using as their theme "Murder in the Stacks," the Fairfield University Library staff, for example, set up two display cases labelled "The Evidence," one of which contained an evening's worth of garbage 
collected in the library and the other the ingenious bookmarks (including the time-honored strip of bacon) used by their patrons. Preservation Comics, which is issued sporadically by Joseph Grant (free from Box 25544, Library Lane, Tempe, AZ 85285), features as its heroine a normal librarian who becomes transformed into a crusading superheroine at the sight of a preservation offense.

Some preservation humor is just the kind of good plain fun that emerges from our fascination with a new field that, on the one hand, carries with it some of the trappings of a science and, on the other hand, offers exciting new solutions to age-old library problems. In one of the earliest known efforts at preservation humor David Weber, in 1965, described the successful conclusion of a project, funded by the Sopwith Graphics Foundation, to develop a new felt tip pen ink containing a soluble pigment, $99.3 \%$ of which is absorbed into the fibers of book paper within 48 to 72 hours, thus eliminating the damage caused by users who underline and otherwise deface library books through the use of the more common felt tip pen. Despite Weber's assertion that these new improved pens would be available nationally within a year of his announcement, they have yet, alas, to appear on the market.

A more recent anonymous missive about Project Omega urges, with the usual whereases and resolveds, the use of self-destructing paper, properly labelled, in books as a contribution to the effective elimination of the massive cataloging backlogs so common in academic libraries. That approach is welcome in part, of course, because it hearkens back to some of the earliest work of the Molesworth Institute. Some have even been foolhardy enough to suggest that preservation techniques might be used with librarians. In one of the most widely reprinted pieces of contemporary library humor, which seems to have first been published in Cum Notis Variorum the newsletter of the Music Library of the University of California at Berkeley in about 1982/1983, S.Q.F. deals with "The Storage and Care of Librarians" urging that they be stored in the dark since they "decompose when exposed to light." Another recommendation in that classic piece has to do with the provision of adequate shelving for oversize librarians since "the ruggedness of structure of such librarians is rarely commensurate with their size, their weight, and with beatings they take because of their inherent unwieldiness."

Sometimes, as is often the case with satirical humor, an underlying touch of concern, protectiveness, or even jealousy surfaces. As new library programs, such as preservation, develop and compete with established programs for scarce resources, some of us may see in the apparent favored status of those programs a threat to support for our own efforts. Good-natured, if sometimes snide, attacks on the typical crusading fervor of most preservation librarians may be a way of expressing that latent hostility. That may in part be what lies behind the description of the rise and fall of preservation efforts at the Ohio State University Library between 1986 and 1988 as reported in News Nosey (see box below). The story begins with the announcement in 1986 of the creation of fourteen new positions ranging from Preservation Library Director to Preservation Library Clerk II. In 1987 there is a report on how the new get-tough approach has led to the creation of yet another five new positions ranging this time from Preservation Kommandant to Preservation Dog Handler II. In 1988 there is the gleeful announcement of the termination of the "Librerries Preservative Office" since the Director has decided that "every book should be allowed to die with dignity." All preservation positions have been reassigned on a permanent temporary basis to an equally useless new Search Committee Department.

\section{Feeling funny?}

Your response has improved, but please keep those (business) cards and (news)letters coming. Other descriptions, reports, stories, and tales of the creative use of humor to spice up academic libraries and librarianship are also most welcome.

Special thanks go to Susan Logan (aka S. Log-On) of the Ohio State University Libraries for sending me no less than nine wonderful, fun-filled issues of an irregular newsletter (now titled News Nosey) that has been distributed anonymously - but widely suspected to be masterminded by the clever genius Mike Valinisthere since at least 1982. Described most recently as the newsletter of The Ahia State Multiversity Liberries, News Nosey takes a satirical look at the real issues facing that library (e.g., "Tex, burly but handsome steward for Local 411, United Cockroaches of America, wishes to notify the OSUL staff cockroaches that the staff lounge will be the site of the 1982 national U.C.A. convention") and especially the foibles of its administrators (e.g., the establishment in 1984 of the Rubber Stamp Committee "to give formal approval to any of the administration's decisions").

One theory is that such creative endeavors may surface when staff morale is low and staff are unhappy with their work situation. I subscribe to the somewhat naive but more optimistic theory that such endeavors reflect a situation in which staff feel comfortable in analyzing the problems that face them with a sharp eye, because they are working in a healthy environment where such efforts are endured if not encouraged and appreciated. Other examples of April Fool's newsletters, and similar insider attacks on a library establishment, would be especially appreciated as grist for an eventual lengthy article on that topic. Please send all such stuff, as usual, to: Norman D. Stevens, 143 Hanks Hill Road, Storrs, CT 06268. 
The proclamation in an issue of The Library Muse from the University of Missouri Library proclaiming April as Book Desecration Month, along with the presentation of the official Don't Care Bear symbol, may be, in part, an effort to focus attention on untoward user behavior but it too carries with it just a hint of discomfort about preservation efforts. The description and illustration in that same issue of Saint Asafoetida-the Patron Saint of Book Preservation, also known as the Blessed Fumigator-who "felt the call of her venerated profession and abandoned library school to wander through the midwestern libraries spreading the Doctrine of Preservation" clearly expresses the concern that many librarians seem to have with the too ardent dedication of their colleagues who have seen the preservation light. In their zeal those colleagues can become easy targets for fun. For that we should be thankful.

Our concerns may be especially evident when those nasty preservation librarians attempt to impose their doctrines in ways that affect the personal habits of users and/or staff in relationship to the consumption of food and drink in the proximity of library materials. As the New York University Libraries videotape and the Fairfield University Library exhibit demonstrate, the damage that food and drink can do to library books is real but reforming the guilty may be more successful, and less resented, if approached with a touch of humor. But those same issues obviously affect library staff who may be just as accustomed as users to a more casual approach to the consumption of food and drink at work. The imposition of the same, or more stringent, standards on library staff as imposed on users - for after all we must be good role modelscan generate outright hostility to that aspect of the preservation cause that may surface through humor. News Nosey reported, for example, in 1985 on a new series of brown bag lectures to which staff were encouraged to bring their brown bags but without food or drink in them. The continuing cockroach battle at the Ohio State University $\mathrm{Li}$ brary (see box below again)-including the description of the discovery of the largest cockroach species known to man-and other aspects of the battle against food and drink in the library, have been featured there in a humorous context but the dividing lines among the library staff have not been clearly drawn.

But whether in simple jest or in earnest satire the important national library effort to address serious preservation concerns does have its lighter aspects. Just as it has added a new dimension to the serious side of librarianship, so it has added a new dimension to the humorous side. That has been an unanticipated and welcome benefit of this vital work.

\section{Applications invited for C\&RL editor}

Nominations and applications are invited for the position of editor of College \& Research Libraries. The editor is appointed for a three-year term which may be renewed for an additional three years. Applicants must be members of ALA and ACRL. Qualifications include experience in academic libraries, evidence of research and editing activity, and a broad knowledge of the issues confronting academic libraries. A small honorarium for the editor and funding arrangements for editorial assistance are available. Nominations or resumes with names of three references may be sent to: C. Brigid Welch, Chair, College and Research Libraries Search Committee, Central University Library, C-075-R, University of California, San Diego, La Jolla, CA 92093. The deadline for applications is May $1,1989$.

\section{Library benefit concerts: Blood, sweat, and cash}

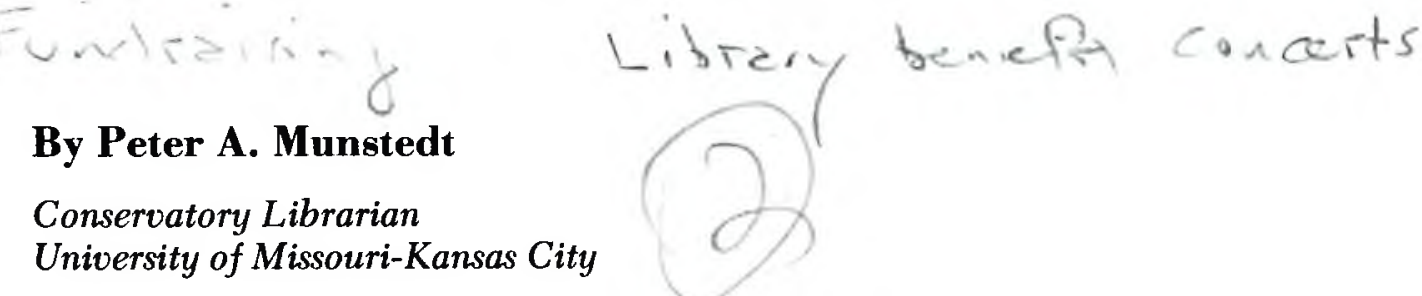

Budget cuts and inadequate funding have increasingly sent academic librarians in search of outside money. Grants are one means of obtaining support, but this funding has become scarce over the years. Finding grants applicable to a library and its particular needs also restricts the possibilities, especially for smaller academic libraries. In these lean financial times for libraries, new and creative approaches are often necessary to supple- ment a budget. As Peter Spyers-Duran points out: "The choice between operative poverty and relative affluence may be determined by the academic library's ability to increase outside support level."1

${ }^{1}$ Peter Spyers-Duran, "Revitalization of Academic Library Programs through Creative FundRaising," in Austerity Management in Academic Libraries, ed. John F. Harvey and Peter Spyers- 